\title{
Decrespignyite-( $Y)$, a new copper yttrium rare earth carbonate chloride hydrate from Paratoo, South Australia
}

\author{
K. Wallwork ${ }^{1, *}$, U. Kolitsch ${ }^{2}$, A. Pring ${ }^{1,3,4}$ and L. Nasdala ${ }^{5}$ \\ ${ }^{1}$ School of Chemistry, Physics and Earth Sciences, The Flinders University of South Australia, GPO Box 2100 \\ Adelaide, South Australia 500, Australia \\ 2 Institut für Mineralogie und Kristallographie, Universität Wien, Geozentrum, Althanstr. 14, A-1090 Vienna, \\ Austria \\ ${ }^{3}$ Mineralogy Department, South Australian Museum, North Terrace, Adelaide, S.A. 5000, Australia \\ ${ }^{4}$ Department of Geology and Geophysics, University of Adelaide, North Terrace, Adelaide, S.A. 5000, Australia \\ ${ }^{5}$ Institut für Geowissenschaften - Mineralogie, Johannes Gutenberg-Universität, D-55099 Mainz, Germany
}

\section{ABSTRACT}

Decrespignyite-(Y) is a new copper yttrium rare earth carbonate chloride hydrate from the Paratoo copper mine, near Yunta, Olary district, South Australia. Decrespignyite-(Y) occurs as blue crusts, coatings and fillings in thin fissures on the slatey country rock. Individual pseudohexagonal platelets are typically $10-50 \mu \mathrm{m}$ in maximum dimension and are often curved. Associated minerals include caysichite-(Y), donnayite-(Y), malachite and kamphaugite-(Y). Electron microprobe and CHN analyses gave: $\mathrm{Y}_{2} \mathrm{O}_{3}$ 42.2; $\mathrm{La}_{2} \mathrm{O}_{3}$ 0.1; $\mathrm{Pr}_{2} \mathrm{O}_{3}$ 0.1; $\mathrm{Nd}_{2} \mathrm{O}_{3} 1.3 ; \mathrm{Sm}_{2} \mathrm{O}_{3}$ 1.0; $\mathrm{Gd}_{2} \mathrm{O}_{3} 4 ; \mathrm{Tb}_{2} \mathrm{O}_{3}$ 0.4; $\mathrm{Dy}_{2} \mathrm{O}_{3}$ 3.7; $\mathrm{Ho}_{2} \mathrm{O}_{3}$ 2.6; $\mathrm{Er}_{2} \mathrm{O}_{3}$ 2.5; $\mathrm{CaO} 0.5 ; \mathrm{CuO} 10.9 ; \mathrm{Cl} 3.0 ; \mathrm{CO}_{2}$ 19.8; $\mathrm{H}_{2} \mathrm{O}$ 10.8, yielding an empirical formula of $\left(\mathrm{Y}_{3.08} \mathrm{Gd}_{0.22} \mathrm{Dy}_{0.16} \mathrm{Ho}_{0.11} \mathrm{Er}_{0.10} \mathrm{Nd}_{0.06} \mathrm{Sm}_{0.05} \mathrm{~Tb}_{0.02} \mathrm{La}_{0.02} \mathrm{Pr}_{0.01} \mathrm{Ca}_{0.08}\right)_{\Sigma 3.91} \mathrm{Cu}_{1.12}\left(\mathrm{CO}_{3}\right)_{3.70-}$ $\mathrm{Cl}_{0.7}(\mathrm{OH})_{5.79} \cdot 2.4 \mathrm{H}_{2} \mathrm{O}$. The simplified formula is $(\mathrm{Y}, R E E)_{4} \mathrm{Cu}\left(\mathrm{CO}_{3}\right)_{4} \mathrm{Cl}(\mathrm{OH})_{5} \cdot 2 \mathrm{H}_{2} \mathrm{O}$. The mineral is royal blue to turquoise-blue in colour, transparent, with a pearly to vitreous lustre and a pale blue streak. No cleavage was observed but the morphology suggests that cleavage would be on $\{010\}$. The Mohs' hardness is estimated to be 4 . The strongest lines in the X-ray powder pattern are $\left[d_{\mathrm{obs}}\left(I_{\mathrm{obs}}\right)\right.$ $(h k l)] 22.79$ (30) (010); 7.463 (30) (001); 7.086 (50) (011); 6.241 (100) (021); 4.216 (30) (112); 3.530 (40) (022); $3.336(30)(032) ; 2.143(30)(222, \overline{401})$. The powder diffraction pattern was indexed on a monoclinic cell with $a=8.899(6), b=22.77(2), c=8.589(6) \AA, \beta=120.06(5)^{\circ}, V=1506.3(7) \AA^{3}$ and $Z=4$. The structure of the new mineral could not be determined but powder diffraction data indicate the space group is $P 2, P m$ or $P 2 / m$. The measured density is $3.64(2) \mathrm{g} / \mathrm{cm}^{3}$ and the calculated density is $3.645 \mathrm{~g} / \mathrm{cm}^{3}$. Decrespignyite-(Y) is biaxial negative with $\alpha=1.604(4)$ and $\gamma=1.638(3)$ with $\beta$ very close to $\gamma$; pleochroism is medium strong; $\mathrm{X}$ very pale bluish, $\mathrm{Y}$ and $\mathrm{Z}$ bluish (with greenish tint). Decrespignyite-(Y) is a supergene mineral which precipitated from mildly basic carbonated ground waters. The mineral is named after Robert Champion de Crespigny, a prominent figure in the Australian mining industry and chancellor of the University of Adelaide.

Keywords: decrespignyite-(Y), new mineral, rare earth carbonates, Paratoo deposit, South Australia.

\section{Introduction}

THE Paratoo copper deposit is a small supergene copper deposit located $30 \mathrm{~km}$ south-west of Yunta, on the western edge of the Olary

* E-mail: pring.allan@saugov.sa.gov.au

DOI: $10.1180 / 0026461026610021$
Province of South Australia $\left(32^{\circ} 41^{\prime} \mathrm{S}, 139^{\circ} 20^{\prime} \mathrm{E}\right)$. The deposit has been worked intermittently since 1889 (Brown, 1908; Woodcock, 1966; Nixon, 1967). Further small-scale exploration work was done in the 1960s. The rare earth mineralization at the site remained unrecognized until samples of a bright blue mineral were submitted for identification by an Adelaide collector, Mr John Toma in 1998. Additional material was subsequently 
collected by two of the authors (U.K. and A.P.). The bright blue mineral proved to be a new copper yttrium rare earth carbonate chloride hydrate and the characterization and description of this mineral is the subject of this paper. A reexamination of specimens in the micromount collection of the late J.E. Johnson, housed at the South Australian Museum, revealed a specimen of decrespignyite-(Y) (labelled as azurite) which had been collected at the Paratoo copper mine before 1967.

The new mineral, decrespignyite-(Y), is named for Mr Robert James Champion de Crespigny (born in 1950), executive chairman of Normandy Mining Limited, Chancellor of the University of Adelaide and Chairman of the South Australian Museum, in recognition of his contribution to the Australian Mining Industry and Australian education. The mineral and the name were approved by the IMA Commission on New Minerals and Mineral Names (2001-027). The type material is held in the collection of the South Australian Museum, Adelaide (G25453, G25454, G25455).

\section{Occurrence}

An outline of the general geology and mineralization style of the Paratoo deposit $\left(32^{\circ} 41^{\prime} \mathrm{S}\right.$ $\left.139^{\circ} 20^{\prime} \mathrm{E}\right)$ was given by Nixon (1967). The copper mineralization (malachite) at Paratoo is hosted in the Auburn dolomite, a lenticular silty and carbonaceous dolomitic unit in the upper Burra group of Neoproterozoic age (Drexel et al., 1993). In the immediate vicinity of the deposit, there is a diapiric breccia with carbonate matrix containing rafts of contorted siltstones, sandstones and dolomites and "diorites intruding diapirs". It is thought that the copper mineralization may have been deposited from hydrothermal fluids associated with the diorite intrusions. Nixon (1967) reported chalcopyrite in goethite and concluded that much of the goethite within quartz veining in the deposit is the result of oxidation of the primary copper and iron sulphides. Most of the copper mineralization is supergene in origin, but the source of the rare earth elements and their mobility is not clear. The most common copper mineral at the deposit is malachite. Decrespignyite-(Y) occurs with a number of other rare earth minerals including white crusts and plate-shaped pseudomorphs of caysichite-(Y) and colourless to pale grey pseudohexagonal plates of donnayite-(Y). Both minerals appear to have formed more or less contemporaneously with decrespignyite-(Y). Pale greyish globular kamphaugite-(Y) often forms thin coatings on decrespignyite-(Y). Other minerals found with decrespignyite-(Y) include malachite, nontronite, 'limonite' pseudomorphs after pyrite, calcite (encrusting decrespignyite(Y)), and gypsum.

Other rare earth minerals found at the deposit but not in direct association with decrespignyite(Y) include pale blue round aggregates of a Y-rich bastnäsite-(La) and pale pinkish white acicular crystals of a Y-rich calcio-ancylite-(Nd). There is also at least one unknown rare earth mineral, a very pale blue monoclinic $\mathrm{Ca}-\mathrm{La}-\mathrm{Cu}$-carbonate which occurs as platy aggregates with malachite and Y-rich bastnäsite-(La). The characterization of this latter mineral is currently under way and more details of this interesting rare earth mineral assemblage at the Paratoo copper mine will be published in the near future (Kolitsch, 2002).

Decrespignyite-(Y) formed as a supergene mineral on narrow fissures of a fine-grained, inhomogeneous dolomitic slatestone which contains small authigenic platelets of muscovite. Decrespignyite-( $(\mathrm{Y})$ is associated with caysichite(Y) for which Hogarth et al. (1974) suggested transportation in mildly acidic carbonated groundwaters, with precipitation occurring when the $\mathrm{pH}$ was increased to a value approaching neutrality.

Both the association with malachite, donnayite- $(\mathrm{Y})$ and chalcedony, and the presence of other minerals found at the mine site, such as chrysocolla, calcite, gypsum and baryte, suggests mineral formation took place under conditions of intense weathering in an arid climate, probably at neutral or slightly basic $\mathrm{pH}$ and oxidizing conditions (Williams, 1990), with evaporation of saline groundwaters playing an important role. The $\mathrm{pH}$ did probably did not exceed a value of 9.5 since this is the maximum value of groundwaters in the natural environment (Garrels and Christ, 1965). The presence of goethite pseudomorphs after pyrite also indicates that weathering processes have proceeded under arid conditions (Boyle, 1997). Some decrespignyite-(Y) is encrusted or pseudomorphed by kamphaugite-(Y). Other pseudomorphs observed are amorphous Mn oxide after malachite and chrysocolla after malachite.

The source of the $\mathrm{Y} / R E E$ in decrespignyite-( $(\mathrm{Y})$ and the other rare earth carbonate minerals at the deposit is currently unknown. No primary Y- or $R E E$-mineral was observed on any specimens from the mine workings and dumps. As the 
occurrence of the mineral in the mine is very localized, it is assumed that the $\mathrm{Y}$ and the other $R E E$ are derived from one or more sediment horizons strongly enriched in these elements (with the $\mathrm{Sr}$ in the donnayite-(Y) also coming from a sedimentary source).

\section{Physical and optical properties}

Decrespignyite-(Y) occurs as crusts, up to $5 \mathrm{~mm}$ thick, coatings and fillings in thin fissures in a finegrained, inhomogeneous slatestone. Less commonly it occurs as free-grown globular aggregates of thin pseudohexagonal crystals (Fig. 1). Individual platelets are typically $10-50 \mu \mathrm{m}$ in maximum dimension, but $<0.5 \mu \mathrm{m}$ thick. The groups of free-grown crystals have the appearance of chrysanthemum blooms (Fig. 2). The colour of decrespignyite-(Y) varies from an intense royal blue (No $110 \mathrm{~B}$ on the Royal Horticultural Society colour chart) to turquoiseblue (No $111 \mathrm{~B}$ on the RHS chart) and the streak is pale-blue (No $110 \mathrm{C}$ on the RHS chart). The mineral is transparent with a vitreous to pearly lustre. In thin-section decrespignyite-( $\mathrm{Y})$ is very pale blue. Optical properties were determined using Cargille immersion liquids in white light, but due to the tiny size of the individual crystals the optical properties could not be characterized completely. Decrespignyite-(Y) is biaxial negative with $\alpha=1.604(4)$ and $\gamma=1.638(3)$ with $\beta$ very close to $\gamma$ (white light). Pleochroism is medium strong; $\mathrm{X}$ very pale bluish, $\mathrm{Y}$ and $\mathrm{Z}$ bluish (with greenish tint), and absorption is $\mathrm{Z} \approx \mathrm{Y}>\mathrm{X}$. The $2 \mathrm{~V}$ and the dispersion could not be measured but

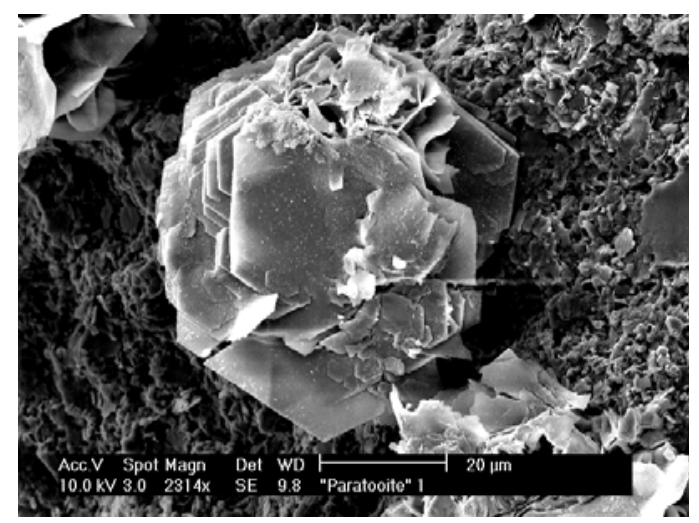

FIG. 1. SEM micrograph of a single decrespignyite-(Y) rosette, showing the pseudohexagonal habit of the thin plates.
$2 \mathrm{~V}$ must be very small. Neither short-wave $(253 \mathrm{~nm})$ nor long-wave ultraviolet light excitation $(366 \mathrm{~nm})$ resulted in notable emission of luminescence light. The density was measured using the suspension method, with Clerici's solution diluted with water. The measured density was found to be $3.64(2) \mathrm{g} / \mathrm{cm}^{3}$. This value is in excellent agreement with the calculated density of $3.645 \mathrm{~g} / \mathrm{cm}^{3}$ (calculation based on the empirical formula and $Z=4$ ). The Mohs' hardness of aggregates of decrespignyite-( $(\mathrm{Y})$ crystals is 2; that of the individual crystals could not be measured but is estimated to be 4 , based on the hardness of other Y carbonates. Due to the small crystal size and in particular the thinness of the platy crystals, no cleavage was observed. However, given the morphology it seems likely that if there is a cleavage it will be on $\{010\}$.

\section{Chemistry}

Chemical analyses of decrespignyite-(Y) were performed using a Cameca CAMEBAX SX51 electron microprobe operated at $15 \mathrm{kV}$ and a specimen current of $20 \mathrm{nA}$. The spot size was set at $5 \mu \mathrm{m}$ in order to reduce beam damage and volatilization. The standards used for wavelength dispersive analysis were $\mathrm{LaF}_{3}, \mathrm{PrF}_{3}, \mathrm{NdF}_{3}, \mathrm{Y}, \mathrm{Sm}$, $\mathrm{Gd}, \mathrm{Tb}, \mathrm{Dy}, \mathrm{Ho}, \mathrm{Er}$ and $\mathrm{Cu}$ metals, wollastonite $(\mathrm{Ca})$, halite $(\mathrm{Cl})$ and albite $(\mathrm{Na})$. Care was taken when selecting background positions to avoid overlaps with lines of rare earth elements. In addition to the elements reported above the following elements were sought but not found: $\mathrm{Si}, \mathrm{P}, \mathrm{Al}, \mathrm{Ce}, \mathrm{Lu}, \mathrm{Sr}$ and F. No other elements

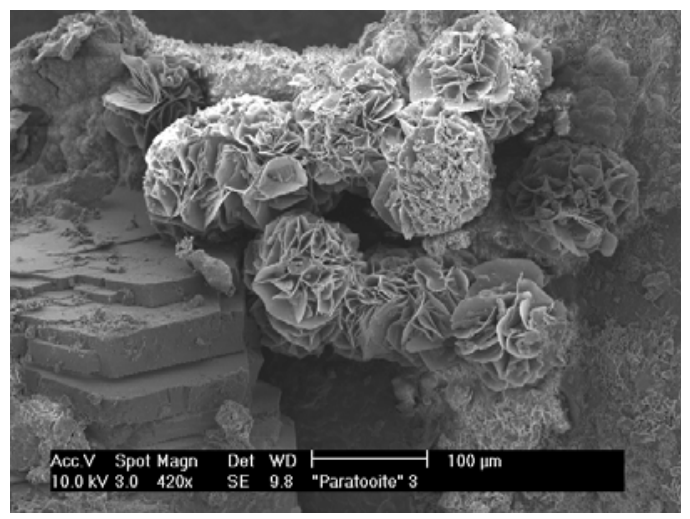

FIG. 2. SEM micrograph of rosette-like aggregates of decrespignyite-(Y). The large thick plates in the lower left area are donnayite-(Y) crystals. 
with $Z>9$ were detected by a WDS scan. Variable amounts of $\mathrm{Na}$ were found in analyses from the outer part of the decrespignyite-(Y) balls but no Na was detected in the central region and it was concluded that $\mathrm{Na}$ was associated with coating of sodium-rich kamphaugite-(Y). Carbonate and water contents were determined by CHN analysis (Gribbles Analytical Laboratories) on a carefully hand-picked sample of $\sim 20 \mu \mathrm{g}$ from the type specimen. The combined totals from the $\mathrm{CHN}$ and electron microprobe analyses are somewhat high $(103 \%)$; this may reflect loss of $\mathrm{H}_{2} \mathrm{O}$ during probe analysis, thus giving oxide proportions for partially dehydrated decrespignyite-(Y). Semiquantitative EDS analyses showed some minor variation in the $R E E$ abundances for decrespignyite-(Y) from different sites at the deposit but, in general, the $(\mathrm{Y}+R E E): \mathrm{Cu}$ ratio appears to be constant. Analytical data are presented in Table 1. Calculation of the empirical formula posed some problems as the mineral has no clear close relationship to any other mineral or synthetic compound. An inspection of the average volume occupied by anions $(\mathrm{O}, \mathrm{F}, \mathrm{Cl})$ in various yttrium rare earth carbonates gave a figure of $\sim 18-20 \AA^{3}$ per anion. This indicated a formula based on

TABLE 1. Electron microprobe analysis of decrespignyite-(Y).

\begin{tabular}{lcc}
\hline & Wt.\%* & Range \\
\hline $\mathrm{Y}_{2} \mathrm{O}_{3}$ & 42.2 & $40.9-44.0$ \\
$\mathrm{La}_{2} \mathrm{O}_{3}$ & 0.3 & $0.2-0.4$ \\
$\mathrm{Pr}_{2} \mathrm{O}_{3}$ & 0.1 & $0.0-0.2$ \\
$\mathrm{Nd}_{2} \mathrm{O}_{3}$ & 1.3 & $1.2-1.4$ \\
$\mathrm{Sm}_{2} \mathrm{O}_{3}$ & 1.0 & $0.7-1.0$ \\
$\mathrm{Gd}_{2} \mathrm{O}_{3}$ & 4.8 & $4.4-5.2$ \\
$\mathrm{~Tb}_{2} \mathrm{O}_{3}$ & 0.4 & $0.3-0.7$ \\
$\mathrm{Dy}_{2} \mathrm{O}_{3}$ & 3.7 & $3.4-4.0$ \\
$\mathrm{H}_{2} \mathrm{O}_{3}$ & 2.6 & $2.3-2.8$ \\
$\mathrm{Er}_{2} \mathrm{O}_{3}$ & 2.5 & $2.2-2.8$ \\
$\mathrm{CaO}$ & 0.5 & $0.5-0.5$ \\
$\mathrm{CuO}$ & 10.9 & $9.9-11.4$ \\
$\mathrm{Cl}$ & 3.0 & $2.6-3.3$ \\
$\mathrm{CO}$ & 19.8 & \\
$\mathrm{H}_{2} \mathrm{O}$ & 10.8 & \\
$\mathrm{O}=\mathrm{Cl}$ & -0.7 & \\
$\mathrm{Total}$ & 103.2 & \\
\end{tabular}

\footnotetext{
* Mean of 7 analyses. $\mathrm{H}_{2} \mathrm{O}$ and $\mathrm{CO}_{2}$ determined by
} $\mathrm{CHN}$ analysis somewhere between 78 and 84 anions in the unit cell. A formula based on 80 anions was found to give a calculated density very close to the observed value and to give cation ratios near integer values, which were simple multiples of 4 . Thus, the calculations suggest that $Z=4$, a figure consistent with a monoclinic space group. The empirical formula based on 20 anions is $\left(\mathrm{Y}_{3.08} \mathrm{Gd}_{0.22} \mathrm{Dy}_{0.16} \mathrm{Ho}_{0.11} \mathrm{Er}_{0.10} \mathrm{Nd}_{0.06} \mathrm{Sm}_{0.05}\right.$ $\left.\mathrm{Tb}_{0.02} \mathrm{La}_{0.02} \mathrm{Pr}_{0.01} \mathrm{Ca}_{0.08}\right)_{\Sigma 3.91} \mathrm{Cu}_{1.12}\left(\mathrm{CO}_{3}\right)_{3.7} \mathrm{Cl}_{0.7}$ $(\mathrm{OH})_{5.79} \cdot 2.4 \mathrm{H}_{2} \mathrm{O}$ and the simplified formula is $(\mathrm{Y}, R E E)_{4} \mathrm{Cu}\left(\mathrm{CO}_{3}\right)_{4} \mathrm{Cl}(\mathrm{OH})_{5} \cdot 2 \mathrm{H}_{2} \mathrm{O}$. The absence of $\mathrm{Ce}$ in the mineral indicates that the $\mathrm{Eh}$ at the time of formation was high enough to fractionate it as $\mathrm{Ce}^{4+}$ elsewhere.

Decrespignyite-(Y) quickly reacts with dilute $\mathrm{HCl}$ with effervescence. The mineral dissolves slowly in cold $10 \% \mathrm{HNO}_{3}$, but reacts rapidly, with effervescence and discolouration, when the solution is heated.

\section{X-ray crystallography}

X-ray powder diffraction patterns of decrespignyite-(Y) were obtained using a $100 \mathrm{~mm}$ diameter Guinier-Hägg camera with $\mathrm{Cr}-K \alpha_{1}$ radiation $(\lambda=2.28970 \AA)$ and $\mathrm{Si}$ as an internal standard. The 010 reflection at $d=27.79 \AA$ was just visible in the back reflection plane in the Guinier pattern. Powder patterns were also obtained using a $114.6 \mathrm{~mm}$ Gandolfi camera using $\operatorname{Co}-K \alpha$ radiation $(\lambda=1.79021 \AA)$ and without an internal standard. This gave highangle diffraction data $(d<2.0 \AA)$. The diffraction patterns obtained on these two cameras are summarized in Table 2.

As part of an ongoing project into the determination of crystal structures of microcrystalline minerals by $a b$ inito powder X-ray diffraction methods, a powder diffraction pattern of decrespignyite-(Y) was also collected using synchrotron radiation $(\lambda=0.7012 \AA)$ on a highresolution powder diffractometer at the Photon Factory at Tsukuba, Japan. Attempts to solve the crystal structure from these data were not successful, but during fitting of the pattern using the Le Bail profile fitting method with RIETICA (Le Bail et al., 1988; Hunter, 1998) the following unit cell was obtained: $a=8.8944(6), b=$ 22.884(2), $c=8.5759(6) \AA, \quad \beta=119.990(4)^{\circ}$. This cell was refined during the profile fit on the position of 1047 reflections. The Guinier data were indexed on the basis of the Le Bail profile and gave a slightly smaller cell with $a=8.899(6)$, 
TABLE 2. X-ray powder diffraction data for decrespignyite-(Y).

\begin{tabular}{|c|c|c|c|c|c|c|c|c|c|}
\hline$I / I_{0}$ & $d^{1}(\mathrm{obs})$ & $d^{2}(\mathrm{obs})$ & $d$ (calc.) & $h k l$ & $I / I_{0}$ & $d^{1}(\mathrm{obs})$ & $d^{2}(\mathrm{obs})$ & $d$ (calc.) & $h k l$ \\
\hline 30 & 22.79 & & 22.772 & 010 & 20 & 2.273 & 2.273 & 2.272 & 162,043 \\
\hline 10 & 11.42 & 11.54 & 11.386 & 020 & 10 & 2.261 & & 2.260 & 082 \\
\hline 30 & 7.463 & 7.38 & 7.432 & 001 & 20 & 2.173 & 2.184 & 2.173 & 212 \\
\hline 50 & 7.086 & 7.044 & 7.066 & 011 & 30 & 2.143 & 2.143 & 2.143 & $222, \overline{4} 01$ \\
\hline 100 & 6.241 & 6.238 & 6.224 & 021 & 10 & 2.073 & & 2.072 & $\overline{4} 42,063, \overline{3} 14$ \\
\hline 5 & & 5.952 & & & 10 & 2.063 & 2.066 & 2.063 & $\overline{4} 31, \overline{2} 34$ \\
\hline 5 & 5.321 & 5.299 & 5.311 & 031 & 10 & 2.051 & & 2.048 & $\overline{1} 14$ \\
\hline 10 & 4.506 & 4.538 & 4.519 & 041 & 10 & 2.025 & 2.027 & 2.025 & 281 \\
\hline 20 & 4.293 & 4.283 & 4.289 & $111, \overline{1} 02$ & 10 & 1.986 & 1.989 & 1.987 & $\overline{4} 43$ \\
\hline 30 & 4.216 & 4.219 & 4.218 & $\overline{1} 12$ & 10 & 1.955 & & 1.953 & $\overline{3} 44$ \\
\hline 20 & 4.015 & 4.009 & 4.017 & $\overline{1} 22$ & 20 & & 1.944 & 1.942 & 0.10 .2 \\
\hline 5 & & 3.887 & 3.884 & 051 & 10 & 1.913 & & 1.913 & $\overline{3} 91$ \\
\hline 20 & 3.734 & 3.746 & 3.733 & $\overline{2} 12, \overline{1} 32$ & $10 \mathrm{~b}$ & & 1.887 & & \\
\hline 10 & 3.719 & & 3.716 & 002 & 5 & & 1.852 & & \\
\hline 20 & 3.662 & 3.665 & 3.668 & 012 & $20 \mathrm{~b}$ & & 1.805 & & \\
\hline 40 & 3.530 & 3.539 & 3.533 & 022 & 5 & & 1.768 & & \\
\hline 5 & & 3.428 & 3.428 & 142 & $10 \mathrm{~b}$ & & 1.725 & & \\
\hline 10 & 3.379 & & 3.387 & $\overline{2} 32,601$ & 20 & & 1.700 & & \\
\hline 30 & 3.336 & 3.344 & 3.338 & 032 & 20 & & 1.688 & & \\
\hline 10 & 3.251 & & 3.253 & 070 & 5 & & 1.655 & & \\
\hline $30 \mathrm{~b}$ & & 3.138 & $3.152 / 3.124$ & $\overline{2} 42, \overline{1} 52$ & 10 & & 1.621 & & \\
\hline 10 & 2.872 & & 2.875 & $\overline{3} 12,052,161$ & 10 & & 1.589 & & \\
\hline 10 & 2.845 & & 2.847 & 080 & 20 & & 1.558 & & \\
\hline 10 & 2.802 & 2.792 & 2.793 & $221, \overline{1} 03, \overline{2} 13$ & $5 b$ & & 1.523 & & \\
\hline 10 & 2.784 & & 2.782 & 113 & $5 b$ & & 1.483 & & \\
\hline 10 & 2.722 & 2.732 & 2.725 & $\overline{3} 31, \overline{1} 23$ & 5 & & 1.457 & & \\
\hline 10 & 2.654 & & 2.656 & 062,132 & 20 & & 1.433 & & \\
\hline 10 & 2.631 & 2.636 & 2.629 & $\overline{1} 33$ & 10 & & 1.418 & & \\
\hline 10 & 2.594 & & 2.593 & $\overline{1} 72, \overline{3} 41$ & 5 & & 1.370 & & \\
\hline 10 & 2.568 & & 2.568 & 300 & $20 \mathrm{~b}$ & & 1.318 & & \\
\hline 20 & 2.459 & 2.464 & 2.458 & $\overline{3} 51$ & $10 \mathrm{~b}$ & & 1.283 & & \\
\hline 10 & 2.420 & & 2.421 & 023 & $10 \mathrm{~b}$ & & 1.222 & & \\
\hline $10 \mathrm{~b}$ & & 2.401 & 2.401 & $\overline{2} 53, \overline{1} 91$ & 10 & & 1.176 & & \\
\hline 10 & 2.389 & & 2.387 & $\overline{1} 53$ & $5 b$ & & 1.125 & & \\
\hline 20 & 2.349 & 2.350 & 2.355 & 033 & & & & & \\
\hline
\end{tabular}

${ }^{1} 100 \mathrm{~mm}$ Guinier-Hägg camera, $\mathrm{Cr}-\mathrm{K} \alpha$ radiation $(\lambda=2.2909 \AA)$; Si internal standard. Intensities estimated visually

$2114.6 \mathrm{~mm}$ Gandolfi camera, Co- $K \alpha$ radiation $(\lambda=1.79021 \AA$ ). Polycrystalline sample. Intensities estimated visually $\mathrm{b}=$ broad line/reflection.

$b=22.77(2), c=8.589(6) \AA, \beta=120.06(5)^{\circ}$. The difference in the $b$ repeat of the two cells probably reflects a zero point error in the low-angle data for the Guinier pattern. An inspection of the powder diffraction data from the Le Bail fit of the synchrotron pattern revealed no systematic absences which indicates the following possible space groups: $P 2, P m$ or $P 2 / m$.

Electron diffraction patterns were obtained using a JEOL 200cx transmission electron microscope operating at an accelerating voltage $200 \mathrm{kV}$. Diffraction patterns down the [010] axis were obtained readily and confirmed the $a$ and $c$ repeats and the $\beta$ angle but it was not possible to get electron diffraction patterns containing the $b$ repeat due to the highly platy habit of the mineral. Diffraction patterns obtained are consistent with a primitive monoclinic lattice.

\section{Vibrational spectroscopy}

Raman spectra of decrespignyite-(Y) were obtained by means of a Renishaw RM 1000 system. This notch filter-based Raman spectrometer was equipped with Leica DMLM series optical microscope, gratings with 1800 grooves per $\mathrm{mm}$, and Peltier-cooled charge-coupled device (CCD) detector. Spectra were excited with the 
$\mathrm{Ar}^{+} 5145 \AA$ line $(0.3 \mathrm{~mW}$ measured after the objective). The Leica $100 \times$ objective (numerical aperture 0.95) was used. Spectra in the range $100-4000 \mathrm{~cm}^{-1}$ were obtained in the "continuous extended scan' data collection mode. The spectral resolution was $2.5 \mathrm{~cm}^{-1}$. For further experimental details see Nasdala and Massonne (2000). Infrared absorption spectra were obtained using a ThermoNicolet Continuum IR microscope equipped with liquid $\mathrm{N}_{2}$-cooled $\mathrm{MCT}$ detector. Reflachromat objectives $(32 \times$; numerical aperture 0.65 ) were used. Crystal flakes were placed on a $\mathrm{ZnSe}$ sample holder for analysis and absorption spectra were measured in the transmitted light mode. The sample masking apertures were adjusted to a $10 \times 20 \mu \mathrm{m}$ large area. Spectra in the range $750-4000 \mathrm{~cm}^{-1}$ were accumulated for $300 \mathrm{~s}$ (signal/background). The spectral resolution was $4 \mathrm{~cm}^{-1}$.

Typical Raman and IR absorption spectra of decrespignyite-(Y) are shown in Figs 3 and 4, respectively. Recall that intensities of Raman and IR absorption bands generally have strong orientational dependencies (e.g. Rousseau et al., 1981). Since the sample volumes analysed with both methods were on the order of the particle size of the analysed mineral sample, multiple analyses of tiny crystals having random orientation were performed with both methods to avoid major orientational effects.

The Raman spectrum of decrespignyite-( $(\mathrm{Y})$ is dominated by strong and narrow bands in the range $1050-1100 \mathrm{~cm}^{-1}$ that are assigned to stretching vibrations of planar $\mathrm{CO}_{3}$ groups. The observation of three bands instead of one (see inset in Fig. 3) suggests that there may exist at least three different $\mathrm{CO}_{3}$ sites with slightly differing symmetries in this carbonate structure. Two Raman bands at 3419 and $3463 \mathrm{~cm}^{-1}$ are assigned to $\mathrm{O}-\mathrm{H}$ stretching vibrations of either hydroxyl groups or water molecules. Their comparably low vibrational frequencies indicate strong hydrogen bonding ( $c f$. Libowitzky, 1999). Vibrational bands with frequencies below $1000 \mathrm{~cm}^{-1}$ are perhaps due to bending vibrations of the $\mathrm{CO}_{3}$ groups, librational vibrations involving the hydrous species, and lattice modes. However, detailed band assignment is not yet possible. The IR spectrum of decrespignyite-(Y) (Fig. 4) confirms the presence of $\mathrm{CO}_{3}$ groups. It shows a marked $\mathrm{O}-\mathrm{H}$-stretching band at $3416 \mathrm{~cm}^{-1}$ and gives, in addition, clear evidence for the presence of water molecules (see the asymmetric absorption band at $1646 \mathrm{~cm}^{-1}$, which is assigned to $\mathrm{H}-\mathrm{O}-\mathrm{H}$ bending).

\section{Relationship to other minerals}

Decrespignyite-( $(\mathrm{Y})$ is the first transition metalbearing yttrium or rare earth carbonate mineral to be described. To the best of our knowledge, no synthetic compounds of this type exist. Establishing structural relationships for decrespignyite-(Y) is, therefore, somewhat difficult.

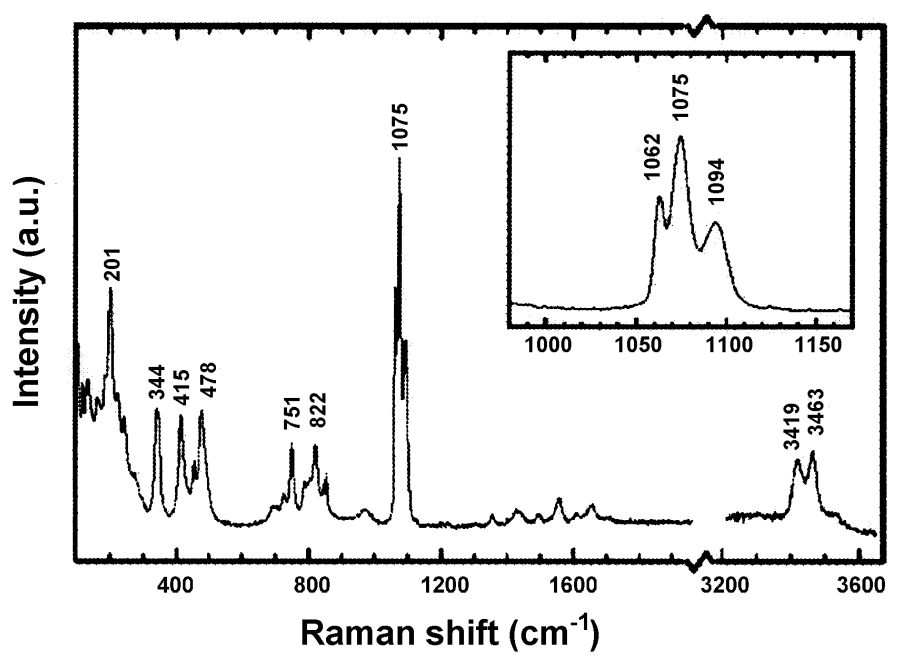

FIG. 3. Raman spectrum of decrespignyite-(Y). The inset is a spread of the spectral region around $1100 \mathrm{~cm}^{-1}$, which shows that there exist several different $\mathrm{CO}_{3}$-stretching bands. 


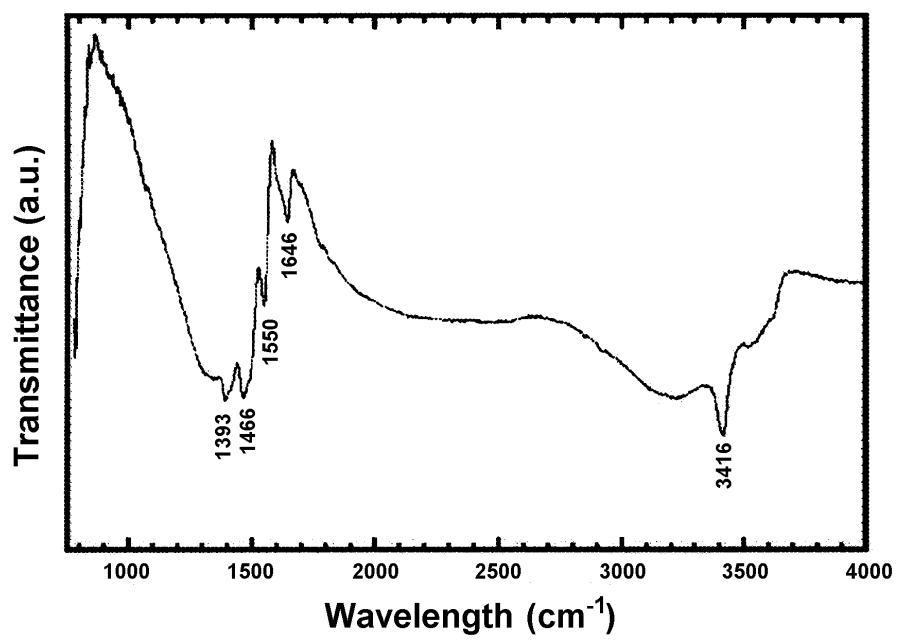

FIG. 4. Typical IR absorption spectrum of decrespignyite-(Y).

However, the occurrence of decrespignyite-(Y) with other $\mathrm{Y}$ and REE carbonate and copper carbonate minerals suggests that the structure of the new mineral is likely to share some common structural features with these minerals. The minerals of the bastnäsite-synchysite-parisite group all adopt hexagonal or pseudohexagonal layer structures based on the stacking of $R E E$ $\mathrm{CO}_{3}-(\mathrm{F}, \mathrm{OH})$ units which have a layer spacing of $\sim 4.8 \AA$ (Ni et al., 1993, 2000). This spacing corresponds to the height of a $(R E E, \mathrm{Y})(\mathrm{O}, \mathrm{F})_{9}$ polyhedron and the length of an edge of a carbonate group. The copper oxyhalide compounds, $\beta-\mathrm{Cu}(\mathrm{OH}) \mathrm{Cl}$ (Voronova and Vainshtein, 1973) and $\mathrm{Cu}_{2}(\mathrm{OH})_{3} \mathrm{Cl}$ (botallackite) (Hawthorne, 1985) are both layer structures consisting rafts of edge-sharing $\mathrm{Cu}(\mathrm{O}, \mathrm{Cl})_{6}$ octahedra which are linked by $\mathrm{H}$ bonding. The thickness of the octahedral layer, ignoring the inter layer gap due to $\mathrm{H}$ bonding is $\sim 3.3 \AA$. The platy pseudohexagonal morphology and the $22.8 \AA$ repeat of decrespignyite-(Y) also suggest a layer structure. The stoichiometry, $(\mathrm{Y}, R E E)_{4} \mathrm{Cu}\left(\mathrm{CO}_{3}\right)_{4} \mathrm{Cl}(\mathrm{OH})_{5} \cdot 2 \mathrm{H}_{2} \mathrm{O}$ may indicate a structure composed of $4 \times(\mathrm{Y}, R E E)\left(\mathrm{CO}_{3}\right)(\mathrm{OH})$ $(4 \times 4.8 \AA)$ and one layer of $\mathrm{CuCl}(\mathrm{OH}) \cdot 2 \mathrm{H}_{2} \mathrm{O}$ $(3.3 \AA)$, perhaps similar to elements of the $\mathrm{Cu}(\mathrm{OH}) \mathrm{Cl}$ structure. The composition of decrespignyite- $(\mathrm{Y}),(\mathrm{Y}, R E E)_{4} \mathrm{Cu}\left(\mathrm{CO}_{3}\right)_{4} \mathrm{Cl}(\mathrm{OH})_{5} \cdot 2 \mathrm{H}_{2} \mathrm{O}$, has considerable similarities to that of kamphaugite-( $\mathrm{Y}), \mathrm{Ca}_{2}(\mathrm{Y}, R E E)_{2}\left(\mathrm{CO}_{3}\right)_{4}(\mathrm{OH})_{2} \cdot 3 \mathrm{H}_{2} \mathrm{O}$ (Raade and Brastad, 1993; Rømming et al., 1993), since the $\mathrm{Ca}$ and $(\mathrm{Y}, R E E)$ cations have a broadly similar coordination in these types of minerals, although the radius of $\mathrm{Ca}$ is somewhat larger than that of Y. The formula of kamphaugite-(Y) can be recast as $(\mathrm{Y}, \text { REE }, \mathrm{Ca})_{4}\left(\mathrm{CO}_{3}\right)_{4}(\mathrm{OH})_{2} \cdot 3 \mathrm{H}_{2} \mathrm{O}$ and decrespignyite-( $\mathrm{Y})$ can be seen as kamphaugite(Y) $(\mathrm{Y}, R E E, \mathrm{Ca})_{4}\left(\mathrm{CO}_{3}\right)_{4}(\mathrm{OH})_{4} \cdot \mathrm{H}_{2} \mathrm{O}+$ $\mathrm{Cu}(\mathrm{OH}) \mathrm{Cl}-\mathrm{H}_{2} \mathrm{O}$. Kamphaugite- $(\mathrm{Y})$ has a tetragonal structure with $a=7.43, c=21.8 \AA$, which consists a stacking of mixed $\mathrm{Ca} / \mathrm{Y}$ layers along $\mathbf{c}$ (Rømming et al., 1993). It is also notable that $a_{\text {kamp }}=c_{\text {decr }} \sin \beta_{\text {decr. }}$. This again suggests that the decrespignyite-(Y) structure may contain five layers, four kamphaugite-(Y)-like layers plus a $\mathrm{Cu}-\mathrm{OH}-\mathrm{Cl}$-like layer stacked along $\mathbf{c}$.

A notable feature which emerges when decrespignyite-(Y) is compared with other $\mathrm{Y} / R E E$ minerals is that the refractive indices are comparatively low and the birefringence is small compared to minerals of the bastnäsite-synchysiteparisite group. The refractive indices for synchysite-(Y) are $\omega=1.643, \varepsilon=1.73$, and for kamphaugite-(Y), $\alpha=1.627, \beta=\gamma=1.663$ (Raade and Brastad, 1993), while those of decrespignyite-(Y) are $\alpha=1.604(4)$ and $\gamma=$ $1.638(3)$. It is notable that in highly birefringent carbonates such as synchysite and calcite, carbonate groups are arranged either all parallel to or all perpendicular to the optic axis. The arrangement of carbonate groups in kamphaugite(Y) is that of a corrugated sheet perpendicular to the optic axis and the birefringence is low. This suggests that, structurally, decrespignyite-(Y) is probably more closely related to kamphaugite-(Y) 
than to the bastnäsite-synchysite-parisite group. Some relation between kamphaugite-(Y) and decrespignyite- $(\mathrm{Y})$ is also indicated by the close association of both species.

\section{Acknowledgements}

The authors wish to thank Mr John Toma for providing the first samples of descrespignyite-(Y). Thanks are due to R. Lehnert (Renishaw, Pliezhausen) who made a Raman system available for analysis. We are indebted to $\mathrm{H}$. H. Belz (ThermoNicolet, Offenbach) for assisting in the IR measurements. We thank Dr A. Christy for his constructive review of the manuscript. K.W. wishes to acknowledge the financial support of an Australian Postgraduate Award.

\section{References}

Boyle, D.R. (1997) Iodargyrite as an indicator of arid climatic conditions and its association with goldbearing glacial tills of the Chibougamau-Chapais area, Quebec. Canadian Mineralogist, 35, 23-34.

Brown, H.Y.L. (1908) The Mines of South Australia. Reprint of 4th edition, C.E. Bristow, Adelaide, Australia, $382 \mathrm{pp}$.

Drexel J.F., Preiss, W.V. and Parker, A.J. (1993) The geology of South Australia, Geological Survey of South Australia Bulletin 54, vol. 1, 177-185.

Garrels, R.M. and Christ, C.L. (1965) Solutions, Minerals, and Equilibria. Harper \& Row, New York, USA.

Hawthorne, F.C. (1985) Refinement of the crystal structure of botallackite. Mineralogical Magazine, 49, 87-89.

Hogarth, D.D., Chao, G.Y., Plant, A.G. and Steacy, H.R. (1974) Caysichite, a new silico-carbonate of yttrium and calcium. Canadian Mineralogist, 12, 293-298.

Hunter, B.A. (1998) Rietica - A Visual Rietveld Program. Commission on Powder Diffraction Newsletter, 20, 21.

Kolitsch, U. (2002) Caysichite-(Y), donnayite-(Y), kamphaugite-( $\mathrm{Y})$ and other rare-earth carbonates from the Paratoo copper mine, South Australia (in prep.).

Le Bail, A., Duroy, H., and Fourquet, J.L. (1988) Abinitio structure determination of $\mathrm{LiSbWO}_{6}$ by X-ray powder diffraction. Materials Research Bulletin, 23, $447-452$.

Libowitzky, E. (1999) Correlation of O-H stretching frequencies and $\mathrm{O}-\mathrm{H} \cdots \mathrm{O}$ hydrogen bond lengths in minerals. Monatshefte für Chemie, 130, 1047-1059.

Nasdala, L. and Massonne, H.-J. (2000) Microdiamonds from the Saxonian Erzgebirge, Germany: in situ micro-Raman characterisation. European Journal of Mineralogy, 12, 495-498.

Ni, Y., Hughes, J.M. and Mariano, A.N. (1993) The atomic arrangement of bastnäsite-( $\mathrm{Ce}), \mathrm{Ce}\left(\mathrm{CO}_{3}\right) \mathrm{F}$, and structural elements of synchysite-(Ce), röntgenite-(Ce), and parisite-(Ce). American Mineralogist, 78, 415-418.

Ni, Y., Post, J.E. and Hughes, J.M. (2000) The crystal structure of parisite-(Ce). American Mineralogist, 85, 251-258.

Nixon, L.G.B. (1967) Paratoo copper deposit. Mining Review (Adelaide), Volume Date 1965, No. 123, $8-20$.

Raade, G. and Brastad, K. (1993) Kamphaugite-(Y), a new hydrous $\mathrm{Ca}-(\mathrm{Y}, \mathrm{REE})$-carbonate mineral. European Journal of Mineralogy, 5, 679-83.

Rømming, C., Kocharian, A.K. and Raade, G. (1993) The crystal structure of kamphaugite-(Y). European Journal of Mineralogy, 5, 685-690.

Rousseau, D. L., Baumann, R. P. and Porto, S. P. S. (1981) Normal mode determination in crystals. Journal of Raman Spectroscopy, 10, 253-290.

Voronova, A.A. and Vainshtein, B.K. (1973) Electron diffraction determination of the crystal structure of $\mathrm{Cu}(\mathrm{OH}) \mathrm{Cl}$. Kristallografiya, 18, 106-111.

Williams, P.A. (1990) Oxide Zone Geochemistry. Ellis Horwood, New York, USA, 286 pp.

Woodcock, J.T. (1966) Treatment of Oxidized Copper Ore from Paratoo, South Australia. CSIRO Mining Department, University of Melbourne, Ore Dressing Investation Report No. 666, 9 pp.

[Manuscript received 21 August 2001:

revised 19 November 2001] 